\title{
Antimicrobial activity of Rhodobryum ontariense
}

\author{
Boris Pejin ${ }^{1,2}$, Aneta Sabovljević ${ }^{3}$, Marina Soković ${ }^{4}$, Jasmina Glamočlija ${ }^{4}$, Ana Ćirićc ${ }^{4}$ Milorad Vujičić ${ }^{4}$, \\ Marko Sabovljević ${ }^{3}$ \\ ${ }^{1}$ University of Belgrade, Institute for Multidisciplinary Research, Department of Life Sciences, Belgrade, Serbia \\ ${ }^{2}$ University of Belgrade, Faculty of Chemistry, Department of Organic Chemistry, Belgrade, Serbia \\ ${ }^{3}$ University of Belgrade, Faculty of Biology, Institute of Botany and Botanical Garden, Belgrade, Serbia \\ ${ }^{4}$ University of Belgrade, Institute for Biological Research "Siniša Stanković", Belgrade, Serbia
}

\begin{abstract}
The antimicrobial activity of dimethyl sulfoxide extract of moss Rhodobryum ontariense (Kindb.) Kindb. was evaluated by microdilution method against eight bacterial (Escherichia coli, Pseudomonas aeruginosa, Salmonella typhimurium, Enterobacter cloacae, Listeria monocytogenes, Bacillus cereus, Micrococcus flavus and Staphylococcus aureus) and five fungal species (Aspergillus versicolor, Aspergillus fumigatus, Penicillium funiculosum, Penicillium ochrochloron and Trichoderma viride). The extract was proven to be active against all the bacteria and fungi tested but to varying degrees. It showed better inhibitory activity compared to the known antifungal drug against T. viride (MIC 100 and $200 \mu \mathrm{g} / \mathrm{ml}$, respectively). This finding implies that $R$. ontariense could be considered as a promising material for natural antifungal products.
\end{abstract}

Keywords: Moss, Rhodobryum ontariense, DMSO extract, Antibacterial and antifungal activity.

Available online at the Journal website: http://www.ache.org.rs/HI/

\section{RESEARCH NOTE}

UDC 582.32:547.914:615.322.07

Hem. Ind. 66 (3) 381-384 (2012)

doi: 10.2298/HEMIND120131022P
Bryophytes are the second largest group of terrestrial plants with an estimated number of 20,000 to 28,000 species worldwide [1]. The small size and biomass of these plants have caused them to be neglected for wider use. In fact, they have been long considered to be economically insignificant except for mosses used in packing, plugging and decoration.

However, the antibiotic influence of liverworts $A n$ thoceros, Conocephalum, Jungermannia, Marchantia and Riccia, and mosses Atrichum, Dicranum, Mnium, Polytrichum and Sphagnum has been known for a long time [2]. Many bryophytes have been investigated for their antimicrobial activity [3-8]. Extracts of mosses Meteorium buchananii and Meteorium subpolytrichum have been showed to be highly effective to Staphylococcus aureus [9]. Zinmeister and Asakawa have stated that bryophytes are one of the important sources of antibiotics and biologically active, naturally occurring compounds [10-11]. On the other hand, the antibiotic activity of bryophytes, as another plant groups, varies from species to species. It also depends on the age of the plant, season of collection and the ecological niche [12].

In Serbia the genus Rhodobryum is represented by two species (Rhodobryum roseum and Rhodobryum ontariense), which are not widely distributed [13-14] (Fi-

Correspondence: B. Pejin, Department of Life Sciences, Institute for Multidisciplinary Research, Kneza Višeslava 1, 11000 Belgrade, Serbia.

E-mail: borispejin@imsi.rs; brspjn@gmail.com

Paper received: 7 November, 2011

Paper accepted: 28 November, 2011 gure 1). The aim of this study was to find out if $R$. ontariense could be considered as an interesting source of antimicrobial agents.

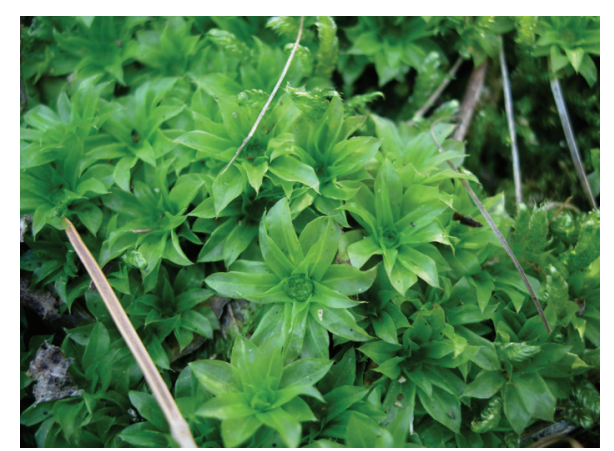

Figure 1. The moss Rhodobryum ontariense in situ (the Deliblato Sands, Serbia).

\section{EXPERIMENTAL}

\section{Plant material}

The moss Rhodobryum ontariense (Kindb.) Kindb. (Bryaceae), collected near Belgrade (the Deliblato Sands, Serbia) in March 2007, was dried and stored at room temperature $\left(25 \pm 2{ }^{\circ} \mathrm{C}\right)$ before extraction. A voucher specimen has been deposited in the Herbarium of the Institute of Botany, University of Belgrade, Serbia (bryophyte collection BEOU No. 4708).

\section{Extraction procedure and microorganisms used}

The green leaves of gametophyte tips used for extraction were dried by airflow at room temperature. 
The extraction was performed by slight rehydratation of dried plant material in dimethyl sulfoxide (DMSO) (10 $\mathrm{mg}$ of the material per $1 \mathrm{ml}$ of the solvent), left in the dark for $12 \mathrm{~h}$, and the extract was filtered with a cellulose-acetate membrane $(0.45 \mu \mathrm{m})$. The DMSO extract was chosen because of its property to be inert and to not show any activity compared to other solvents such as methanol or ethanol, for example. Indeed, for the reason of verifying its toxicity, DMSO alone (in the amount used to dissolve samples) was also tested in this antimicrobial screening and found not to interfere with obtained results.

For adequate bioassays, eight bacteria, four Gramnegative bacteria: Escherichia coli ATCC 35210, Pseudomonas aeruginosa ATCC 27853, Salmonella typhimurium ATCC 13311 and Enterobacter cloacae (human isolate), and four Gram-positive bacteria, Listeria monocytogenes NCTC 7973, Bacillus cereus (human isolate), Micrococcus flavusATCC 10240 and Staphylococcus aureus ATCC 6538, and five fungi, Aspergillus versicolor ATCC 11730, Aspergillus fumigatus ATCC 9142, Penicillium funiculosum ATCC 36839, Penicillium ochrochloron ATCC 9112 and Trichoderma viride IAM 5061, were used. The bacteria were maintained on Mueller-Hinton agar $(\mathrm{MH})$ and Lysogeny broth medium (LB) and the micromycetes on malt agar (MA). Cultures were stored at $4{ }^{\circ} \mathrm{C}$ and subcultured once a month [15].

\section{Screening of antimicrobial activity}

The modified microdilution technique was used to screen antimicrobial activity $[16,17]$. Bacterial species were cultured overnight at $37{ }^{\circ} \mathrm{C}$ in LB medium. The fungal spores were washed from the surface of agar plates with sterile $0.85 \%$ saline containing $0.1 \%$ Tween $80(\mathrm{v} / \mathrm{v})$. The fungal and bacterial cell suspensions were adjusted with sterile saline to a concentration of approximately $1.0 \times 10^{5}$ in a final volume of $100 \mu \mathrm{l}$ per well. The inocula were stored at $4{ }^{\circ} \mathrm{C}$ for further use. Dilutions of the inocula were cultured on solid $\mathrm{MH}$ for bacteria and solid MA for fungi to verify the absence of contamination and to check the validity of the inocula.

Determination of minimal inhibitory concentrations (MICs) was performed by a serial dilution technique using 96-well microtitre plates. The extract was dissolved in DMSO $(10 \mathrm{mg} / \mathrm{ml})$ and added in broth medium with inoculum. The microplates were incubated for $48 \mathrm{~h}$ at $37^{\circ} \mathrm{C}$ for bacteria and for 5 days at $28^{\circ} \mathrm{C}$ for fungi. The lowest concentrations without visible growth (at the binocular microscope) were defined as MICs $[17,18]$. The minimal bactericidal (MBCs) and fungicidal (MFCs) concentrations were determined in triplicate by serial subcultivation of $2 \mu \mathrm{l}$ into microtitre plates containing $100 \mu \mathrm{l}$ of broth per well and further incubation for $48 \mathrm{~h}$ at $37{ }^{\circ} \mathrm{C}$ or 5 days at $28^{\circ} \mathrm{C}$, respectively. The lowest concentration with no visible growth was defined as MBC/MFC respectively, indicating 99.5\% killing of the original inoculum. Streptomycin/ampicillin and bifonazole/ketoconazole were used as positive controls for the bacteria and fungi, respectively.

\section{RESULTS AND DISCUSSION}

The DMSO extract was tested both for antibacterial and antifungal activities. The results for antibacterial activity are presented in Table $1 ;$ MIC and MBC values ranged between 1.00 and $3.00 \mathrm{mg} / \mathrm{ml}$. The most sensitive species was $E$. cloacae, followed by $B$. cereus and $M$. flavus. The most resistant bacterium was $S$. aureus. Standard drugs streptomycin and ampicillin, used as positive controls, were active against all the bacteria. The range of MICs for streptomycin was from 0.05 to $0.10 \mathrm{mg} / \mathrm{ml}$ while MBCs were from 0.05 to $0.30 \mathrm{mg} / \mathrm{ml}$; ampicillin showed lower antibacterial activity with MICs values between 0.10 and $0.30 \mathrm{mg} / \mathrm{ml}$ and MBCs values between 0.15 and $0.50 \mathrm{mg} / \mathrm{ml}$.

Table 1. In vitro antibacterial activity of $R$. ontariense (MIC and $\mathrm{MBC}$ in $\mathrm{mg} / \mathrm{ml}$ )

\begin{tabular}{lccc}
\hline Bacterium & DMSO extract & Streptomycin & Ampicillin \\
\hline S. aureus & $3.00 / 3.00$ & $0.10 / 0.10$ & $0.10 / 0.10$ \\
B. cereus & $1.00 / 2.00$ & $0.05 / 0.05$ & $0.10 / 0.10$ \\
M. flavus & $1.00 / 2.00$ & $0.05 / 0.10$ & $0.10 / 0.15$ \\
L. monocytogenes & $2.00 / 3.00$ & $0.15 / 0.30$ & $0.15 / 0.30$ \\
P. aeruginosa & $2.00 / 2.00$ & $0.10 / 0.20$ & $0.30 / 0.50$ \\
E. cloaceae & $1.00 / 1.00$ & $0.10 / 0.20$ & $0.15 / 0.20$ \\
S. typhimurium & $2.00 / 2.00$ & $0.10 / 0.20$ & $0.10 / 0.20$ \\
E. coli & $2.00 / 2.00$ & $0.10 / 0.20$ & $0.15 / 0.20$ \\
\hline
\end{tabular}

The extract showed better antifungal activity than antibacterial (Table 2); MICs were ranged between 0.10 and $0.50 \mathrm{mg} / \mathrm{ml}$ and MFCs from 0.25 to $1.00 \mathrm{mg} / \mathrm{ml}$. The most sensitive micromycete was $T$. viride in contrast to other tested fungi, which were similarly sensitive. Bifonazole possessed inhibitory activity of 0.10 to $0.20 \mathrm{mg} / \mathrm{ml}$ and fungicidal of 0.20 to $0.25 \mathrm{mg} / \mathrm{ml}$, while ketoconazole showed lower antifungal activity with MICs of 0.20 to $2.50 \mathrm{mg} / \mathrm{ml}$ and MFCs of 0.5 to 3.00 $\mathrm{mg} / \mathrm{ml}$. The fact that extract showed better inhibitory activity against $T$. viride in comparison with bifonazole (MICs 0.10 and $0.20 \mathrm{mg} / \mathrm{ml}$, and MFCs 0.25 and 0.25 $\mathrm{mg} / \mathrm{ml}$, respectively) is encouraging.

According to Borges-Argáez et al., MIC value of 100 to $200 \mu \mathrm{g} / \mathrm{ml}$ is a fair one for plant extract in the search of new anti-infectious agents [19]. Thereby, T. viride, known as a resistant species, has been recently recognized to be pathogenic in immunosuppressed human host [20]. Inferred from these results a potential use of the moss in bio-fungicides production can be assumed. It opens the problem of axenic farming of these threat species in Serbia for the purpose of bio-harvesting. 
Table 2. In vitro antifungal activity of R. ontariense (MIC and MFC in $\mathrm{mg} / \mathrm{ml}$ )

\begin{tabular}{lccc}
\hline Fungae & DMSO extract & Bifonazole & Ketoconazole \\
\hline T. viride & $0.10 / 0.25$ & $0.20 / 0.25$ & $2.50 / 3.00$ \\
P. funiculosum & $0.50 / 1.00$ & $0.20 / 0.25$ & $0.20 / 0.50$ \\
P. ochrochloron & $0.50 / 1.00$ & $0.15 / 0.20$ & $0.20 / 0.50$ \\
A. fumigatus & $0.50 / 1.00$ & $0.15 / 0.20$ & $0.20 / 0.50$ \\
A. versicolor & $0.50 / 1.00$ & $0.10 / 0.20$ & $0.20 / 0.50$ \\
\hline
\end{tabular}

\section{Acknowledgments}

This work was supported by the Ministry of Science and Technological Development of the Republic of Serbia (Research grants Nos. 143015, 143031, 143049 and 173040).

\section{REFERENCES}

[1] A. Sabovljevic, M. Sabovljevic, in: J.N. Govil, V.K. Singh (Eds.), Bryophytes, a source of bioactive and new compounds, Studium Press, Houston, 2008, pp. 9-25.

[2] J.A. McCleary, D.L. Walkington, Mosses and antibiosis, Rev. Bryol. Lichenol. 34 (1966) 309-314.

[3] A. Basile, S. Sorbo, S. Giordano, A. Lavitola, R. Castaldo Cobianchi. Antibacterial activity in Pleurochaete squarrosa extract (Bryophyta). Int. Antimicrob. Agents 10 (1998) 169-172.

[4] A. Sabovljević, M. Soković, M. Sabovljević, D. Grubišić, Antimicrobial activity of Bryum argenteum, Fitoterapia 77 (2006) 144-145.

[5] M. Singh, A.K.S. Rawat, R. Govindarajan, Antimicrobial activity of some Indian mosses, Fitoterapia 78 (2007) 156-158.

[6] B. Dulger, N. Hacioglu, G. Uyar, Evaluation of antimicrobial activity of some mosses from Turkey, Asian J. Chem. 21 (2009) 4093-4096.

[7] H. Mellegard, T. Stalheim, V. Hormazabel, P.E. Granum, S.P. Hardy, Antibacterial activity of sphagnum acid and other phenolic compounds found in Sphagnum papillasum against food-borne bacteria, Lett. Appl. Microbiol. 49 (2009) 85-90.

[8] M. Veljić, A. Durić, M. Soković, A. Ćirić, A. Glamočlija, P.D. Marin, Antimicrobial activity of methanol extracts of Fontinalis antipyretica, Hypnum cupressiforme and Ctenidium molluscum, Arch. Biol. Sci. 61 (2009) 225-229.
[9] R.L. Zhu, D.Wang, L. Xu, R.P. Shi, J. Wang, M. Zheng, Antibacterial activity in extracts of some bryophytes from China and Mongolia, J. Hattori Bot. Lab. 100 (2006) 603-615.

[10] H.D. Zinsmeister, H. Becker, T. Eicher, Moose als quelle bioaktiver naturstoffe, Angew. Chem. 103 (1991) 134$-151$.

[11] H. Asakawa, A. Ludwiczuk, F. Nagashima, M. Toyota, T. Hashimoto, M. Tori, Y. Fukuyama, L. Harinantenaina, Bryophytes: Bio- and chemical diversity, bioactivity and chemosystematics, Heterocycles 77 (2009) 99-150.

[12] R.D. Banerjee, S.P. Sen, Antibiotic activity of bryophytes, The Bryologist 82 (1979) 141-153.

[13] M. Sabovljevic, Bryophyte flora of South Banat (Vojvodina, Yugoslavia), Cryptogam. Bryol. 24 (2003) 241$-252$.

[14] M. Sabovljevic, T. Cvetic, V. Stevanovic, Bryophyte Red List of Serbia and Montenegro, Biodivers. Conserv. 13 (2004) 1781-1790.

[15] C. Booth, in: Fungal Culture Media, J. R. Norris, D. W. Ribbons (Eds.), Academic Press, London \& New York, 1971, pp. 49-94.

[16] R.K. Daouk, S.M. Dagher, J.E. Sattout, Antifungal activity of the essential oil of Origanum syricum L, J. Food Prot. 58 (1995) 1147-1149.

[17] H. Hanel, W. Raether, A more sophisticated method of determining the fungicidal effect of water-insoluble preparations with a cell harvester, using miconazole as an example, Mycoses 31 (1988) 148-154.

[18] M. Soković, L.J.L.D. van Griensven, Antimicrobial activity of essential oils and their components against the three major pathogens of the cultivated button mushroom, Agaricus bisporus, Eur. J. Plant Pathol. 116 (2006) 211-224 .

[19] R. Borges-Argáez, C.I. Canche-Chay, L.M. Peña-Rodríguez, S. Said-Fernández, G. M. Mollina-Sallina, Antimicrobial activity of Diospyros anisandra, Fitoterapia $\mathbf{7 8}$ (2007) 370-372.

[20] D. De Miguel, P. Gómez, R. González, J. Garcia-Suárez, J.A. Cuadros, M.H. Bañas, J. Romanyk, C. Burgaleta, Nofatal pulmonary Trichoderma viride infection in an adult patient with acyte myeloid leukemia: report of one case and review of the literature, Diagn. Micr. Infect. Dis. 53 (2005) 33-37. 


\section{Извод}

\section{АНТИМИКРОБНА АКТИВНОСТ Rhodobryum ontariense}

Борис Пејин ${ }^{1,2}$, Анета Сабовљевић ${ }^{3}$, Марина Соковић ${ }^{4}$, Јасмина Гламочлија ${ }^{4}$, Ана Ћирић ${ }^{4}$, Милорад Вујичић ${ }^{4}$, Марко Сабовљевић ${ }^{3}$

${ }^{1}$ Универзитет у Београду, Институт за мултидисциплинарна истраживања, Одсек за науке о живим системима, Београд

${ }^{2}$ Универзитет у Београду, Хемијски факултет, Катедра за органску хемију, Београд

${ }^{3}$ Универзитет у Београду, Биолошки факултет, Институт за ботанику и Ботаничка башта, Београд

${ }^{4}$ Универзитет у Београду, Институт за биолошка истраживања „Синиша Станковић“, Београд

(Кратко саопштење)

У in vitro испитивању антимикробне активности диметил-сулфоксидног екстракта маховине Rhodobryum ontariense на осам бактеријских (Escherichia coli, Pseudomonas aeruginosa, Salmonella typhimurium, Enterobacter cloacae, Listeria monocytogenes, Bacillus cereus, Micrococcus flavus n Staphylococcus aureus) и пет гљивичних сојева (Aspergillus versicolor, Aspergillus fumigatus, Penicillium funiculosum, Penicillium ochrochloron и Trichoderma viride) коришћена је модификована микродилуциона техника. Дати екстракт у различитој мери показао је активност на све тестиране организме. Његова активност на гљиву T. viride била је јача од активности коју је показао антифунгални лек бифоназол употребљен као позитивна контрола (МИк 100 и $200 \mu \mathrm{g} / \mathrm{ml}$, редом). Овај рад указује на чињеницу да $R$. ontariense представља обећавајући извор природних производа са антифунгалном активношћу.

Кључне речи: Маховина $\bullet$ Rhodobryum ontariense • ДМСО екстракт • Антибактеријска и антифунгална активност 